\title{
Metabolizable energy and nutrient digestibility of detoxified castor meal and castor cake for poultry ${ }^{1}$
}

\author{
João Batista Matos Júnior², Adélio Nunes Dias², Camila Ferreira Delfim Bueno², Priscila \\ Avelino Rodrigues ${ }^{2}$, Álvaro Luís Carvalho Veloso², Daniel Emygdio de Faria Filho ${ }^{2}$
}

\footnotetext{
1 Financiamento: Conselho Nacional de Desenvolvimento Científico e Tecnológico (47331/2007-0).

2 Instituto de Ciências Agrárias, Universidade Federal de Minas Gerais, Montes Claros, Minas Gerais, Brazil.
}

\begin{abstract}
This experiment aimed to determine the metabolizable energy and the digestibility of detoxified castor meal and castor cake nutrients for broilers. A total of 180 Cobb-500 5 M broilers from 21 to 32 days of age was randomly distributed in three treatments with six replicates of 10 broilers -5 males and 5 females. The experimental treatments were a reference-diet and two test-diets composed of $80 \%$ of reference-diet and $20 \%$ of detoxified castor cake or castor meal. The adaptation period ranged from 21 to 27 days of age and the total excreta collection period ranged from 28 to 32 days of age. The detoxified castor meal presented apparent metabolizable energy of 2,032 kcal/kg of natural matter, apparent metabolizable energy corrected for nitrogen balance of $1,829 \mathrm{kcal} / \mathrm{kg}$ of natural matter and the digestibility coefficients of $57.8 \%$ dry matter, $68.4 \%$ crude protein, $10.5 \%$ crude fiber, $35.9 \%$ nitrogen free extract, $80.0 \%$ ether extract and $26.6 \%$ ash. In the detoxified castor cake, the apparent metabolizable energy content was $2,550 \mathrm{kcal} / \mathrm{kg}$ of natural matter, the nitrogen corrected apparent metabolizable energy balance was of $2,320 \mathrm{kcal} / \mathrm{kg}$ of natural matter and the digestibility coefficients of $60.6 \%$ for dry matter, $77.2 \%$ for crude protein, $14.0 \%$ for crude fiber, $45.7 \%$ for nitrogen free extract, $85.4 \%$ for ether extract and $28.2 \%$ for ash. The metabolizable energy and digestibility of nutrients in detoxified castor cake are higher than in the detoxified castor meal.
\end{abstract}

Key Words: broilers, digestibility coefficient, Ricinus communis L., total excreta collection

\section{Introduction}

Biodiesel is a biodegradable fuel derived from renewable sources such as vegetable oils. According to the Agência Nacional do Petróleo, Gás Natural e Biocombustíveis (ANP 2011), since January $1^{\text {st }} 2010$, the diesel oil derived from fossils commercialized throughout the country contains $5 \%$ of biodiesel, causing Brazil to be one of the largest biodiesel producers and consumers in the world, with an annual production of 1.6 billion liters in 2009 and a production capacity of about 4.7 billion liters in January 2010.

There are dozens of vegetable species whose oils can be used to produce biodiesel, among them, the castor bean (Ricinus communis $L$ ). The extraction of castor oil may be mechanic or through solvents, and it derives the castor cake and the castor meal, respectively. The castor cake corresponds to approximately $55 \%$ of the seed weight (Azevedo \& Lima, 2001), and for each ton of processed seed $550 \mathrm{~kg}$ of castor cake is obtained.

Concerning the nutritional composition, the castor meal presents an average in natural matter, $39.2 \%$ crude protein, $1.55 \%$ ether extract, $18.5 \%$ crude fiber, $0.62 \%$ calcium, $0.21 \%$ available phosphorus, $0.01 \%$ sodium, $0.78 \%$ total lysine and $0.61 \%$ total methionine (Rostagno et al., 2005). The castor cake presents $14.4 \%$ of ether extract, $34.5 \%$ crude protein and $6.6 \%$ ashes in its dry matter (Moreira et al., 2003).

Although the nutritional composition allows the castor cake to be used to feed poultry, most part of this by-product has been used as fertilizer due to toxic and allergenic factors present in castor beans. Nevertheless, there are efficient methods of detoxification currently (Anandan et al., 2005; Oliveira et al., 2006) that enable many derived products from castor beans to become potential animal feed.

In order to use the detoxified castor cake and castor meal to feed poultry, the nutrient digestibility and metabolizable energy content have to be known. Rostagno et al. (2005) reported that the castor meal presents 1,484 kcal of metabolizable energy per kg of natural matter for poultry and do not mention the nutrient digestibility values. No scientific studies determining the digestibility and metabolized energy content of castor by-products for poultry were found.

Brazil is one of the largest biodiesel producers in the world, and castor oil has been used for its production. The 
castor cake and the castor meal, by-products of the castor oil extraction, present potential to be used as animal feed; however, we need to know the digestibility of their nutrients and the metabolized energy content so that nutritionists may feel safe to formulate feed. Thus, this experiment was carried out aiming to determine the metabolizable energy content and nutrient digestibility of the detoxified castor meal and castor cake for broilers.

\section{Material and Methods}

The experiment was conducted at the Setor de Avicultura of the Instituto de Ciências Agrárias of Universidade Federal de Minas Gerais, in Montes Claros, Minas Gerais, Brazil. One hundred and eighty broilers of the commercial line Cobb-500 ${ }^{\mathrm{TM}}$ from 21 to 32 days of age were distributed in a completely randomized design with three treatments and six repetitions of ten broilers - five males and five females.

The experimental treatments consisted of a reference diet based on corn and soybean meal (Table 1) and two test diets composed of $80 \%$ of the reference diet and $20 \%$ of the detoxified castor cake or castor meal. In the pre-trial period, from 1 to 20 days of age, broilers received $61 \%$ corn composed feed, $34 \%$ soybean meal, and $5 \%$ supplement, according to the manufacturer's recommendation.

The castor meal and cake were obtained from the castor bean processing industry. The castor meal was obtained

Table 1- Reference diet for broilers used during the experimental period (21 to 32 days of age)

\begin{tabular}{lc}
\hline Ingredient & Growth (kg) \\
\hline Corn & 68 \\
Soybean meal & 27 \\
Supplement ${ }^{1}$ & 100 \\
Total & \\
Chemical composition (in natural matter) & 2908 \\
Metabolizable energy (kcal/kg) & 19.21 \\
Crude protein (\%) & 0.84 \\
Calcium (\%) & 0.61 \\
Total phosphorus (\%) & 0.19 \\
Sodium (\%) & 0.29 \\
Total methionine (\%) & 0.62 \\
Total methionine + total cystine (\%) & 0.91 \\
Total lysine (\%) & \\
\hline 1 &
\end{tabular}

from the castor oil extraction through solvents and the castor cake by separating the oil by pressing. Meal and cake were detoxified according to Oliveira et al. (2006) using $60 \mathrm{~g}$ of micro processed calcium oxide for each $\mathrm{kg}$ of the product to be detoxified. Before mixing with the castor meal and the castor cake, the calcium oxide was diluted into ten parts of water. After eight hours, the castor meal and the castor cake were placed for drying at room temperature. According to Oliveira et al. (2006). Through the technique of detoxification, ricin, which is the main toxic agent of the castor cake and meal, is completely eliminated. The nutritional composition of the toxic and detoxified castor meal and castor cake was determined according to Silva \& Queiroz (2002) (Table 2).

A metabolism trial was carried out by the traditional method of total excreta collection during the period of 21 to 32 days of age. A seven-day period (21 to 27 days of age) of adaptation to the facilities and to the experimental diet was adopted followed by a total collection of a fiveday period (28 to 32 days of age). Trays covered with plastic were installed below the cages to collect the excreta. On the first and last collection days $1 \%$ ferric oxide was added in the diet to identify the excreta from the experimental diets. Excreta collections were performed twice a day, and samples were stored by repetition and immediately frozen $\left(-4^{\circ} \mathrm{C}\right)$. At the end of the experiment, amounts of feed consumed were determined and the excreta were defrosted at room temperature to determine the total excreta produced. Then, the excreta were homogenized and dried in forced ventilation oven at $55 \pm 2{ }^{\circ} \mathrm{C}$ for 72 hours and subsequently ground. Feed and excreta were analyzed for dry matter, crude protein, ether extract, crude fiber, mineral matter, nitrogen free extract and crude energy as described by Silva \& Queiroz (2002). The content of apparent metabolizable energy (AME), the coefficient of AME metabolization, the apparent metabolizable energy corrected by nitrogen balance (AMEn), the coefficient AMEn metabolization and the coefficient of digestibility of dry matter, crude protein, crude fiber, mineral matter, ether extract and nitrogen free extract were calculated according to reports by Sakomura \& Rostagno (2007).

The data were submitted to the normality analyses of the studentized errors (Cramer-Von Mises test) and variance homogeneity (Brown-Forsythe test) and checked for the presence of outliers. After verifying the compliance of these presuppositions, the data were submitted to analysis of variance using the General Linear Model in SAS ${ }^{\circledR}$ procedure (Littell et al., 2002). 
Table 2 - Nutritional composition of the castor meal and castor cake used in the experiment (in the natural matter)

\begin{tabular}{|c|c|c|c|c|}
\hline \multirow[t]{2}{*}{ Nutrient } & \multicolumn{2}{|c|}{ Castor cake } & \multicolumn{2}{|c|}{ Castor meal } \\
\hline & Toxic & Detoxified & Toxic & Detoxified \\
\hline Dry matter (\%) & 90.4 & 91.1 & 92.2 & 91.2 \\
\hline Ether extract (\%) & 10.2 & 8.3 & 5.0 & 1.9 \\
\hline Crude fiber (\%) & 22.6 & 21.9 & 25.5 & 24.8 \\
\hline Nitrogen free extract (\%) & 13.4 & 15.9 & 9.1 & 12.2 \\
\hline Phosphorus (\%) & 0.39 & 0.73 & 0.47 & 0.30 \\
\hline Sodium (\%) & 0.06 & 0.07 & 0.06 & 0.06 \\
\hline Crude energy (kcal/kg) & 4297 & 3790 & 3624 & 3218 \\
\hline
\end{tabular}

Values determined in accordance with the procedures proposed by Silva \& Queiroz (2002).

\section{Results and Discussion}

The castor cake showed a higher content $(\mathrm{P}<0.01)$ of apparent metabolized energy, apparent metabolized energy corrected by nitrogen balance and digestibility coefficients of dry matter, crude protein, crude fiber, nitrogen free extract and ether extract in relation to the castor meal. The experimental treatments did not influence $(\mathrm{P}>0.05)$ the mineral matter digestibility coefficient.

These better results for the castor cake may have been caused by the lower crude fiber content and by the higher fat content from this by-product in relation to the castor meal. The higher fat content stimulates the hormone cholecystokinin release, which stimulates the production of lipases and also proteases, as well as amylases (Bertechini, 2006). In addition, the high fat content decreases the food passage rate (Mateos \& Sell, 1981; Mateos et al., 1982; Andreotti et al., 2004), exposing it to longer enzyme activity from the digestive tract (Bertechini, 2006). Lower fiber content may also have contributed to better energy and nutrient use because the fiber constitutes a physical impairment for the digestive tract enzymes' access to the nutrients. According to the data presented by Bertechini
(2006), diets with high content of crude fiber decrease the nitrogen free extract digestibility in poultry. Besides, Muztar \& Slinger (1980) and Parsons (1984) observed increased amino acid excretion in higher fiber content diets and attributed this effect to the fiber abrasion in the digestive tract, which decreases its digestion and absorption capacity.

Rostagno et al. (2005) reported the value of apparent metabolizable energy corrected by nitrogen balance of $1,484 \mathrm{kcal} / \mathrm{kg}$ of natural matter for the castor meal. In this study, the value obtained was $23.3 \%$ higher, and this difference may be related to variations in the inclusion level of test food in the reference diet (Table 3). The standard experimental protocols suggest that $40 \%$ of the test food should be incorporated into the reference diet (Sakomura \& Rostagno, 2007). However, in this research, due to the high crude fiber content of castor by-products, the level of $20 \%$ was adopted. Other factors that may have contributed to differences in the results are the detoxification methods to which the castor by-products were submitted, according to broilers' gender and age, diet nutrient level, among others. No other papers in the literature about the metabolizable energy level determination of castor byproducts for poultry were found.

Table 3 - Metabolizable energy and nutrient digestibility determined by the total excreta collection method in broilers

\begin{tabular}{|c|c|c|c|}
\hline & Castor meal & Cator cake & CV (\%) \\
\hline AME (kcal/kg of NM) & $2032 b$ & $2555 a$ & 2.3 \\
\hline AME metabolization (\%) & $63.1 \mathrm{~b}$ & $67.4 \mathrm{a}$ & 3.5 \\
\hline AMEn (kcal $/ \mathrm{kg}$ of NM) & $1829 b$ & $2320 \mathrm{a}$ & 2.3 \\
\hline \multicolumn{4}{|l|}{ Digestibility coefficient } \\
\hline Dry matter $(\%)$ & $57.8 \mathrm{~b}$ & $60.6 \mathrm{a}$ & 3.2 \\
\hline Nitrogen free extract (\%) & $35.9 b$ & $45.7 \mathrm{a}$ & 3.7 \\
\hline Ether extract (\%) & $80.0 \mathrm{~b}$ & $85.4 \mathrm{a}$ & 1.8 \\
\hline Mineral matter (\%) & $26.6 \mathrm{a}$ & $28.2 \mathrm{a}$ & 14.4 \\
\hline
\end{tabular}


The bromatological composition and digestibility of the nutrients obtained in this study were used to predict the content of apparent metabolizable energy corrected by nutrient balance using the prediction equations presented by Rostagno et al. (2005). The AMEn values estimated by Rostagno et al. equation (2005) were 1,988 and 1,298 kcal/kg of natural matter for the detoxified castor cake and castor meal respectively. These AMEn values were 14.3 and 28.9\% lower for the detoxified castor cake and castor meal in relation to the values determined in this study.

It is important to emphasize that the detoxified castor cake and the castor meal still remain as an allergenic factor (glycoprotein CB-1A), which, in animal feed, does not cause problems but may cause allergic reactions in humans during handling. Therefore, it is recommended to wear masks, gloves and protective clothing when handling these by-products.

The implementation of the national production program and biodiesel use, which currently already includes $5 \%$ of this biofuel in the diesel, will increase the castor cultivation destined for oil extraction that will be used in biodiesel production. The by-products generated in this extraction, the castor cake and castor meal when detoxified, are potential food for poultry. Nowadays, there are efficient methods to detoxify the castor bean by-products (Anandan et al., 2005; Oliveira et al., 2006) and allow its use in animal feed. These research findings provide support for the nutritionist to use the castor by-products more safely in formulations.

Few studies on the effects on the castor by-products use in poultry feed performance can be found. Ani \& Okorie (2008) studied the inclusion of 0,10,15 and 20\% of detoxified crushed castor seed for broilers in the final stage of raising and concluded that the level of $10 \%$ was sufficient to optimize feed consumption, weight gain and feed conversion. Unpublished data from our research group confirm that in the period from 1 to 40 days of age, the detoxified castor cake may be included in the poultry diet in levels up to $1.25 \%$ to optimize the poultry performance without affecting their carcass characteristics.

\section{Conclusions}

The metabolizable energy and digestibility of nutrients in detoxified castor cake are higher than in the detoxified castor meal.

\section{Acknowledgements}

The authors would like to thank the Conselho Nacional de Desenvolvimento Científico e Tecnológico - CNPq for funding this research (process 47331/2007-0) and providing scientific scholarship to João Batista Matos Júnior and Camila Ferreira Delfim Bueno; and the Fundação de Amparo a Pesquisa de Minas Gerais - FAPEMIG for granting an undergraduate scholarship to Adélio Dias Nunes.

\section{References}

ANANDAN, S.; ANIL KUMAR, G.K.; GHOSH J. et al. Effect of different physical and chemical treatments on detoxification of ricin in castor cake. Animal Feed Science and Technology, v.120, p.159-168, 2005.

ANDREOTTI, M.O.; JUNQUEIRA, O.M.; BARBOSA, M.J. et al. Tempo de trânsito intestinal, desempenho, característica de carcaça e composição corporal de frangos de corte alimentados com rações isoenergéticas formuladas com diferentes níveis de óleo de soja. Revista Brasileira de Zootecnia, v.33, p.870-879, 2004.

ANI, A.O.; OKORIE, A.U. The effect of dehulled and cooked castor oil bean (Ricinus communis L.) meal on performance of broiler starters. Nigerian Journal of Animal Production, v.16 p.54-60, 2008.

AGÊNCIA NACIONAL DE PETRÓLEO, GÁS NATURAL E BIOCOMBUSTÍVEIS - ANP - Available at: <http:// www.anp.gov.br/?pg $=40787 \& \mathrm{~m}=\& \mathrm{t} 1=\& \mathrm{t} 2=\& \mathrm{t} 3=\& \mathrm{t} 4=\& \mathrm{ar}=\& \mathrm{ps}$ $=\&$ cachebust $=1296648070546>$. Accessed on: Jan. 16, 2011.

AZEVEDO, D.M.P.; LIMA, E.F. O Agronegócio da mamona no Brasil. Brasília: Embrapa Informação Tecnológica, 2001. 350p.

BERTECHINI, A.G. Nutrição de monogástricos. Lavras: UFLA, 2006. 301p.

LITTELL, R.C.; STROUP, W.W.; FREUND, R.J. SAS for linear models. 4.ed. Cary: SAS Institute Inc, 2002. 466p.

MATEOS, G.G.; SELL, J.L. Influence of fat and carbohydrate source on rate of food passage of semipurified diets for laying hens. Poultry Science, v.60, p.2114-2119, 1981.

MATEOS, G.G.; SELL, J.L.; EASTWOOD A.J. Rate of food passage (time transit) as influenced by level of supplemental fat. Poultry Science, v.61, p. 94-100, 1982.

MOREIRA, J.F.C.; RODRÍGUEZ, N.M.; FERNANDES, P.C.C. et al. Concentrados protéicos para bovinos. 1. Digestibilidade in situ da matéria seca e da proteína bruta. Arquivo Brasileiro de Medicina Veterinária e Zootecnia, v.55, p.315-323, 2003.

MUZTAR, A.J.; SLINGER, S.J. The effect of dry matter on metabolic and endogenous amino acid excretion in mature cockerels. Nutrition Report International, v.22, p.901-905, 1980.

OLIVEIRA, A.S.; OLIVEIRA, M.R.C.; CAMPOS, J.M.S. et al. Eficácia de diferentes métodos de destoxificação da ricina no farelo de mamona. In: CONGRESSO DA REDE BRASILEIRA DE TECNOLOGIA E PRODUÇÃO DE BIODIESEL, 2., 2006, Brasília. Anais... Brasília: Rede Brasileira de Tecnologia e Produção de Biodiesel, 2006. p.1-6.

PARSONS, C.M. Influence of caecectomy and source of dietary fibre or starch on excretion of endogenous amino acids by laying hens. British Journal Nutrition, v.51, p.541-548, 1984.

ROSTAGNO, H.S.; ALBINO, L.F.T.; DONZELE, J.L. et al. Tabelas brasileiras para aves e suínos: composição de alimentos e exigências nutricionais. Viçosa, MG: UFV, 2005. 186p.

SAKOMURA, N.K.; ROSTAGNO, H.S. Métodos de pesquisa em nutrição de monogástricos. 1.ed. Jaboticabal: FUNEP, 2007. $283 p$.

SILVA, D.J.; QUEIROZ, A.C. Análise de alimentos: métodos químicos e biológicos. 3.ed. Viçosa, MG: UFV, 2002. 235p. 